\title{
PENELITIAN
}

\section{Simbol dalam Arsitektur Masjid}

\author{
Oleh : Fajriyanto
}

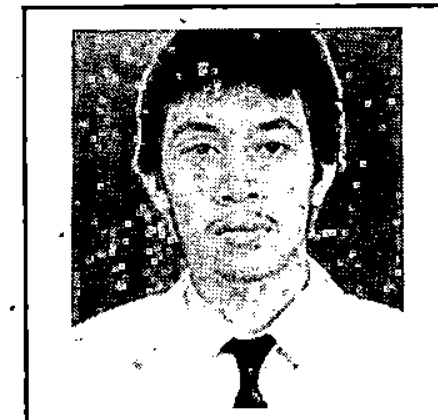

Ir. Fajriyanto, lahirdi Kotagede 1 April 1965 Alumni Fakultas.Teknik Jurusan Arsitektur UGM, tahun 1989 saat ini menjabat sebagai Kepala STUDIO Perencanaan dan Perancangan Arsitektur di Uni- versitas Islam Indonesia dan menjadi Dosen tetap pada Fakultas Teknik Jurusan Arsitektur di Universitas Islam Indonésia sejak tahun 1990.

Pendahuluan

Masjid adalah fasilitas dan wadah yang digunakanumatIslam untuk beribadah kepada Allah SWT, serta kegiatanlain yang berhubungan dengan sosial keagamaan. Masjid merupakan bangunan yang pertama kali didirikan Nabi Muhammad saw untuk membina dan menggalang umat Islam menjadi insan yang bertaqwa. Sehingga masjid sangatlah akrab keberadaannya dengan umat Islam. Bahkan masjid dapat dijadikansebagai tolokukưreksistensi umat Islam di suatụ daerah.

Membahas Arsitektur Islam, maka tidak dapat lepas dari kajian mengenai arsitekturmasjid. Sebabmasjid merupakan bangunan agamani yang terus dibangun oleh umat Islam dipenjuru dunia. Sejak zaman Rasululloh sampai sekarang, pembangunan masjid terus dilaksanakan dan menjadi pusat gerakan Islamiyah.

Membahas arsitektur másjid, dipándang dari segi fisik bangunannya, tentu tidak dapat dilepaskan dari bentuk dan simbol-simbol yang tersirat didalamnya. Simbol merupakan ungkapan untukmengekspresikan makna-makna yàng terkandung di dalamnya: Sehingga pembahasan arsitektur masjid merupakan upaya untuk mengenal, mempelajari dan menggali ajaran Islam dan budaya masyarakat muslim, serta untuk pengembangannya.

Ajaran Islam secara gamblang memang tidak memberikan ketentuanketentuan dalam membangunmasjid secara fisik apalagi yang berupa simbol-simbol fisik yang harus diungkapkan dalam bangunan. Namun bentuk arsitektur masjid, merupakan refleksi budaya suatu masyarakatmuslim dalammengejawatahan ajaran-ajaran Islam. Sehingga masjid akan terus berkembang sebagai pencerminan dari kehidupan manusia berdasarkan ajaran Islam serta interaksi dengan lingkungannya. Ärsitektur masjid kemudian juga menjadi bukti däri tampilnya kebudayaan Islam di tengah perkembangan masyarakat dunia.

\section{Perkembangan Arsitektur Masjid}

Masjid pertama yang dibangun oleh Rasulullah saw. adalah masjid Quba, yang dibangun dengan sangat sederhana sekali. Denah masjid berbentuk segi empat, dengan 
dinding-dinding sebagai pembatasnya. Disepanjang bagian dalam dinding dibưat semacam serambi yang langsung berhubungan dengan lapangan terbuka pada bagian tengah masjid,

Sedangkan pintu masuk dilengkapi dengan tanda atau gerbang yang terdiri dari tumbuhan batu-batu yang diambil dari sekeliling tempatitu:meterial-material yang digunakan adalah bahan-bahan apa adanya sekedar yang terdapat disekeliling tempat itu, sehingga amat sederhana bahan-bahan yang dipergunakan. Materialnya adalah batu-batu alam atau batu-batu gunung, pohon, dahian dan daun kurma. Disini terlihat suatu kaitan alamiah yang wajar dengan alam lingkungannya, dimana bahanbahan bangunan dipergunakan sesuai dengan sifat-sifat alamiahnya.

Masjid Quba merupakan masjid lapangan, karena yang menjadi unsur utamanya adalah lapangan di bagian tengah yang dikelilingnya dinding sebagai pembatasnya. Mảsjid ini kemudianmenjadi pola dasar yang utama bagi masjid-masjid yang dibangun kemudian.

Perkembangan masjid yang benarbenar dianggap sebagai permualaan perkembangan, terjadi pada kurun waktu sesudah wafatnya Nabi Muhammad saw, pada saat sahabat-sahabat nabi sebagai khálifah. Langkah pertama yang dilakukannya adalah pemugaran dan penyempumaan pada masjid yang 'telah ada. Sedangkan perkembangan pembangunan masjid-masjid baru terjadi sekitar tahun enamratusan sampai abad kedelapan.

Perkembangan masjid adalah sejalan dengan perkembangan agama Islam, karena masjid merupakan fasilitas untuk membina masyarakat Islam. Sehingga dimana terjadi gerakan dakwah Islamiyah, maka sudah pasti masjid dijadikan sebagaj sarana keagamaan. Pada saat itu tercatatlah kotakota yang kemudian memberikan bukti adanya perkembangan masjid yang cukup menonjol. Perkembangannya adalah dimulai dari jazirah Arab, sampai ke Mesopotania, kemudian Turkestan, Afrika Utara, lalu menyeberang ke Jibraltar terus menuju ke Spanyol dan Perancis Selatan.

Mulaai abad kesebelas, gerakan penyebaran agama Islam dipelori oleh bangsia Turki. sebagai hasil dari gerakan bangsa Turki ini, masjid berkembang pesat di kawasan Asia Kecil dengan penampilan yang khas. Akibatdari terjadinya pembauran adat kebiasaan asli Turki, maka dengan sendirinya terjadi pula penambahan bentukbentuk pada mäjjid.

Akibat lainnya adalah timbulnya kemungkinan baru dalam penampilan bentuk masjid, yaitu dengan dipergunakannya lengkungan-lengkungan yang terutama ditempatkan pada pintu-pintu masuk, untuk memperoleh kesan ruang yang lebih luas dan tinggi. Penggunaan kubah sebagai atap dan pemakaian bentuk lengkung.pada pintu, merupakan pengaruh dari kebudayaan Persia. Namun pemakain bentuk-bentuk pada masa-masa kemudian bahkan sampai sekarang senantiasa dihubungkan dengan ciri simbolis khas bangunan Islam, yang sebenamya hanyalah semata-mata terjadi karena tuntutan perkembangan arsitektur belaka.

Pada setiap dekade masa perkembangan masjid selalu memberikan gambarannya masing-masing. Usaha perluasan bangunan dan perbaikan masjid menjadi salah satu kegiatan tokoh-tokoh yang ada pada masa memegang kekuasaan. Khalifah yang dikenal sebagai pembangun masjid adalah Al-Walid dari dinasti Umayyah. Olehnya mulai diperkenalkan 
penambahan 'minaret', yang berupa menara, yang dipergunakan untuk menyampaikan adzan.

\section{Simbol Sebagai Bahasa dalam Arsitektur}

Membahas masalah simbol dalam arsitektur; maka tidak dapat lepas dari permasalahan bentuk, karena bentuk memberikan citra visual kepada pengamat. Bentuk dalàm arsitektur adalah suatú unsur yang tertuju pada jiwa dan akal budi s manusia. Benda dan ukurannya saling bekerjasama untukmenghasilkan nilai-nilai dan emosi. Dengan demikian bentuk merupakan suatu media atau alat komunikasi untukmenyampaikan arti yang dikandung oleh bentukitu sendiri atau untuk menyampaikan pesan tertentu dari arsitek kepada masyarakat, atau kepada penerima. Dengan kata lain bentukmerupakan bahasa dalam arsitektur, yang melalui bentuk dapat disampaikan peran dan arti yang terkandung didalam bangunan kepada masyarakat.

Simbol merupakan salah satu yang mewujudkan bentuk, di samping fungsi, bahan dan 'struktur. Simbol besar perananannya dalam mengungkapkan makna-makna yang terkandung dalam bangunan. Melalui simbol-smbol inilah bangunan menjadi lebih bermakna, mampu menyampaikan atau berkomunikasi dengan pengamat. Sehingga simbol dapat berperan sebagai bahasa dalam arsitektur.

Didalam kehidupan bermasyarakat, manusia membutuhkan identitas baik bagi dirinya maupun benda-benda di sekelilingnya. Identitas ini merupakan kebutuhan manusia akan aktualisasi diri. Identitas dapat ditampilkan secaragamblang maupun dengan simbol-simbol.

MenurutSuwondo B. Sutedjo (1982) ada beberapa cara mengungkapkan simbol dalam bentuk bangunan. Diantaranya adalah dengan simbol sebagai metafora, simbol sebagai tersamar yang menyatakan peran dari suatu bentuk, dan simbol sebagai unsur pengenal

\section{Simbol sebagai metafora}

Masyarakat cenderung untuk melihat suatu bangunan dengan membandingkan antara bangünan yang diamati dengañ bangunan atau benda lain. Cara ini ditangkap dalam persepsi untuk memahami simbol dan -bentuk bangunan modern yang semakin kompleks

Sebagaicontoh adalah bangunan Sydney Opera House, di Australia. Bangunan yang mempunyai atap berbentuk'Shells' ini dapat dipersepsikan sebagai tigakurakura yangsedang bergendongan. Namun adapula yang memberikan persepsi sebagai perahu yang sedang membentangkan layamya.

\section{Simbol sebagai tersamar yang} menyatakan peran dari suatu bentuk Dalam konteks ini fungsi merupakan suatu yang - dominan - dalam mengungkapkan bentuk bangunan. Sehingga simbol yang tersirat dalam bentuk adalah merupakan fungsi atau - kebutuhan kegiatan didalamnya

\section{Simbol sebagai unsur pengenal}

dalam hal ini simbol berfungsi sebagai pengenal kepada masyarakat, baik secara fungsional maupun lambangnya. Cara ini ditempuh dengan menggunakan bentuk-bentuk yang telah dikenalumum oleh masyarakat; sebagai tanda atau ciri suatu bangunan. Sehingga- bentuk merupakan simbol dari bangunanbangunan tertentu. Contohnya adalah pemakaian kubah pada masjid. Sehingga 
masyarakat- mẹngenăli masjid dari bentuknya yang menggunakan kubah.

\section{Ungkapan Simbol pada Arsitektur Masjid di Jawa}

Islam merupakan agama yang mempunyâi sifat toleransi yang cukup besar, sepanjang tidak bertentangandengan hukum-hukum yang telah disyariatkan oleh AllahSWT. Sehingga pada saat penyebaran agama Islam ke penjüru dunia, masyarakat muslim tidak merusak bangunan-bangunan yang telah ada sebelumnya. Hal inilạh yang memungkinkan terjadinya proses akulturasi antara ajaran Islam dengan budaya daerah.

Proses akulturasi ini juga terjadi di. Indonesia. Sehingga pada masa awal penyebaran Islam, bangunan-bangunan ibadah yang berupa masjid mempunyai bentuk sesuai dengan arsitektur daerảh. Dengan demikian tidak merusak tatanan lingkungan fisik yang sudah ada, bahkan' lebih memperkaya kebudayaan suatu. daerah.Dan pada dasamya Islam memang tidak menentukan tatanan fisik ataupun bentuk bangunan yang hanus̀ mengikuti suatu model bentuk tertentu.

Masjid Jawa adalah salah satu contoh sukses dari proses akulturasi ini. Dan kemudian masjid ini menjadi pola dasar dari bentuk-bentuk masjid ini menjadi pola dasar dari bentuk-bentuk masjid lain di Jawa, khususnya Jawa Tengah

Masjid Jawa mempunyai-atap yang berbentuk tajüg yang terdiri dari 3 susun atap. Bentuk àtap seperti ini sebenamya telah digunakan oleh masyarakat Jawa sebelum Islam masuk sebagai bangunan. agamani, yaitu pada masa agama Hindu. Namun setelah ajăran Islam masuk, maka fungsi, tatanan ruang dan filosofinyạ yang. kemudiandisesuaikan dengan ajaran Islam dan kebutuhan masyarakat, tanpa harus . mengambil bentuk baru atau berbeda sama sekali dengan bentuk sebelumnya. Filosofi dari atap susun tiga adalah sebagai lambang keabadian Tuhan dan keesaan Tuhan.

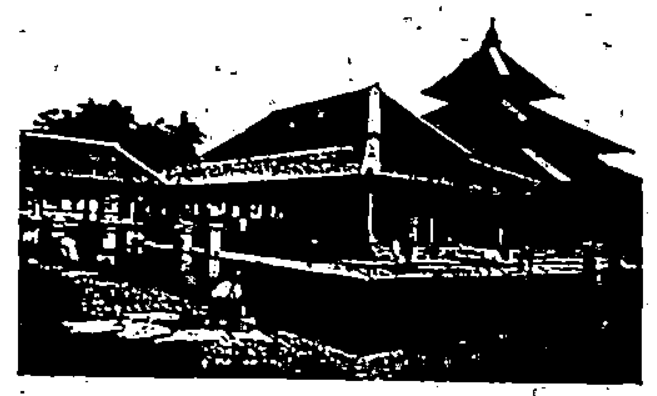

Masjid Besar Mataram Yogyakarta, atap tajug menyampaikan pesan simbol masjid. (sumber: Rabarja)

Pada masjid Jawa terdápat ruang tengah yang dikelilingi serambi pada tiga sisinya. Konsep seperti ini sebenamya telah adapada masjid Quba, masjid pertama yang dibangun Rasululloh saw. Namun pada masjid Quba, ruang tengah berupa lapangan yang dikelilingi serambi pada sisi-sisinya.

- Penggunaan atap tajug untuk bangunan masjid, kemudian memasyarakat dan menjadi model dalam membangun bentuk masjid dan bahkan sampai sekarang. Sehingga sejalan dengan perkembangan waktu dan melalui proses adaptasi, atap tajug akhimya menjadi simbol, sebagai unsur pengenal dan identitas untuk . bangunan masjid di Jawa, khususnya Jawa Tengah.

Penggunaan atapkubah danelemenelemen lengkung merupakan dari bentuk masjid yang ada di Timur Tengah. Pemakaian elemen-elemen ini ternyata diterima juga oleh masyarakat, sehingga pemakaian kubah dan elemen lengkung. telah memasyarakat dan menjadi simbol baru-maupún pelengkap dari simbol sebelumrya pada masyarakat Jawa. 
Pada masjid Jawà, yạng umumnya dibangun dan didanai olẻh masyarakat, umumnya bentuk kubah berukuran kecil yang diletakkan di puncak atap tajug. - Pemakaian Kubah pada atapini sebenamya hanyalah menggantikan mustaka yang berarti kepala, yang terletak pada atap masjid Jawa tradisional. Mustaka pada masjid Jawa tradisional umumnya terbuat dari bahan seng, mempunyai bentuk dari sétiliran dari berbagai daun. Padaumumnya masyarakätmengartikan bahwapemakaian ragam hias mustaka itu mengingatkan pada unsur-unsur kehinduan, sehingga masyarakat menggantikan dengan kubah berbentukkecil. Masyarakat padaumumnya menginterprestasikan bahwa bentuk itu menunjukkan unsur keislaman (Dakung. 1981)

\section{Diskusi : Simbol Sebagai Karakter Pembentuk Arsitektur Masjid}

Didalam Islam; fungsi merupakan suatu yang lebih diutamakan daripada simbol-simbol. Pada bangunan masjid pertama yang didirikan Rasululloh saw. adalah berpangkal pada prinsip " fungsionalisme" untuk mencukupi kebutuhan akan sarana ibadah (Abdul Rochym, 1983).Pelaksanaankonstruksinya alamiyah dengan penyelesaian yang sederhana, tapi dapat secepatnya digunakan.Bentuk-bentuk tambahan sebagai simbol-simbol kelengkapan masjid bukanlah tujuan utama yang mengandung unsur agama sebagai suatu hal yang mutlak diperlukan.

Motivasi dalam membangun niasjid adalah suatu hal yang mutlak diutamakan, dibanding dengan simbol dan bentuk masjid. Pembangunan masjid yang ditujukan untuk menunjukkan suatu perlambang atau simbol kèkuasaan, kemegahan (kerajaan, pemerintahan) merupakan suatu tindakan yang keliru. Meskipun secara fisik, masjid tampak mengagumkan dengan penyelesaian arsitektur yang estetis, namun secara esensi mengandung kekosongan. Hal ini dapat dihubungkan dengan firman Allah swt. dalam surat At-Taubah ayat 108 - 109:

"........Sesungguhnya masjidyang didirikan atas dasar taqwa, sejakharipertamaadalah lebih patut kamu-sholat didalamnya. Didalamnya ada orang-orang yang ingin membersihkan diri. Dan Ảllah menyukai orang-orang yang bersih. Maka apakah orang-orang yang mendirikan masjidnya diatas dasar taqwa kepada Allah dan keridaan-(Nya) itu yang baikm, ataukah orang-orang yang mendirikan bangunannya ditepi jurang yang runtuh, lalu bangunnya itu jatuh bersama-sama dengan dia ke dalam neraka jahanam? Dan Allah tidak memberikan petunjuk kepada orang-oraing yang zalim"

Pembahasan simbol dalam arsitektur masjid disini bukanlah ditujukan untuk melebihkan simbol dan bentuk arsitektur masjid dari segi fungsi dan motivasi. Akan tctapi lebih ditujukan untuk menggali kebudayaan Islam.

Sebagaimana diketahui Islam sebagai agama, bérpengaruh terhadap perilaku dankehidupan masyarakat muslim; yang akhimya akan membentuk sistem sosial dankebudayaan masyarakat muslim. Sehingga masjid sebagai wadah kegiatan keaganiaan masyarakāt muslim merupakan pencerminan dari sistem sosial dan kebudayaan masyarakat pendukungnya.

Pada masa awal lahimya Islam, masjid disamping berfungsi sebagai tempat ibadah, juga pernah berfungsi sebagai pusat kegiatan politik, administrasi dan peradilan. 
Disamping itu fungsi masjid juga berhubungan dengan ilmu pengetahuan, kesenian dan filsafat. Pada perkembangan selanjutnya, masjid telah bergeserke fungsi tunggal, yaitu sebagai tempat beribadah dan tabligh ajaran Islam.

Perubahan fungsi masjid ini berdampak pada kedudukannya dalam struktur sosial budaya masyarakat. Sehingga yang nampak sekarang masjid hanya berkedudukan sebagai sebuah elemen dari suatu lingkungan urbar dan bukan sebagai pembentuk urban atau sebagai pusat gereja yang dahulu hanya berfungsi sebagai tempatperibadatan umat Nasrani, sekarang cenderung menuju ke suatu kompleks: bangunan yang multi fungsi. Hal ini dimaksudkan untukmenarikminat generasi muda untuk kembali ke gereja.

MenurutSidi Gazalba(1962), masjid seharusnya berfungsi sebagai pusat kebudayaan. Upaya kearah itu, sesungguhnya merupakan suatu langkah yang cukup maju, meskipun hal itu bukanlah suatu pekerjaan yang mudah, apalagi di tengah masyarakat yang heterogen. Namun melihat kondisi saat ini, terdapat hal yang lebih penting untuk menjadikan masjid sebagai pusat orientasi. Kedudukan masjid seharusnya berperan , sebagai pengorganisasian ruang dan bangunan dalam lingkungan; sebagai dasar dan manifestasi dalam penataan lingkungan. Sehingga masjid menjadi simbol kedamaian, pemersátu dan orientasi suatu kawasan.

Menarik diamati, bahwa banyak masjid di Yogyakarta yang hadir ditengah komunitas, lebih dapat berperan sebagai ruang pemersatu dari lingkungan ketetanggaan, menjadi tempat kegiațan sosialkemasyarakatan serta tempat bermain anak-anak. Sedangkan lokasi masjid yang berada dipinggir jalan besar (utama), cenderung dimanfaatkan oleh orang-orang yang lewat dalam perjalanan yang bersifat insidental. Sehingga masjid hanya ramai pada saat tertentu, misalnya hari jum'at dan setelah itu lengang. Hal ini menunjukkan bahwa lokasi masjid berperanan dalam menjadikan masjid sebagai pusat orientasi lingkungan ketetanggaan.

Simbol menupakan suatu perlambang yang berperan sebagai bahasa untuk menunjukkan fungsi dan identitasnya. Pada saat sekarang, mewujudkan suatu ekspresi bentuk arsitektur yang islami merupakan suatu debat yäng berkepanjangan. Masjid sebagai bangunan arsitekturyang terpenting dalam mengungkapkan identitas muslim, selalu menjadi perhatian yang utama. Perdebatannya umumnya berkisar pada mempertemukan antara tradisi dan modem dalam mendesain arsitektur masjid.

Menurut Hasan Udin Khan (1991) secara arsitektural bangunan masjid yang dibangun selama kurun waktu 40 tahun yang lalu, terbagai dalam empat kategori pokok sebagai berikut : ,

- Vernakuler, dimana bangunan masjid diterjemahkan dengan bahasa arsitektur tradisional dan cara ini sampai sękarang masih digunakan.

- Historis, dimana beberapa modelnya menunjukkan kembali ke gaya-gaya historis yang spesifik, sebagai sumber didalam mendesain. Beberapa masjid menggunakan lebih dari satu gaya dan hadir dengan suatu gaya campuran.

- Klasik Kontemporer, dalam istilah barat disebut sebagai post-modem sebagaimana ditulis oleh William Curtis. Pendekatan ini menggunakan referensi gaya historis yang secara umum dianǵgap sebagai 'klasik' dalam Islam, namun menghadirkan kesadaran untuk mencari interprestasi 
kembali dari model-model ini. Pada beberapa kasus hal ini menuju kesuatu eklektism (memilih dari berbagai sumber) dan beberapa diantaranya menjadi suatu sintesa yang cukup menarik.

- Modern, dimana desain, image, dan teknologi menunjukkan suatu keterputusan hubungan dengan masa lalu, untuk memperlihatkan identitas muslim yang modem. Biasanya karya ini' adalah hasil dari arsitek-arsitek yang dididik secara formal (menurut pengertian Barat) serta pemberi tugas yang berpendidikan. Jadi usahamerupakan sesuatu yang menentukan.

Namun ungkapan simbol dan bentuk dalam arsitetur masjid ternyata sangat dipengaruhi juga oleh sumber pendanaan dan pengambil keputusan dalam membangun masjid. Sumber dana yang berbeda-beda, misalnya swadaya masyarakat, pemerintah, intitusi atau suatu lembaga, nampak memperlihatkan suatu ungkapan simbol yang berbeda-beda terasa dipaksakan. Sebagai contoh adalah lahimya gaya resmi yang diharikan melalui desain masjid yang terstandar, yang didanai oleh Yayasan Amal Bhakti Pancasila. Desain masjid ini telah menyebar di seluruh Indonesia. Sehingga menurut Yuswadi Saliya (1991), mungkin membentuk suatu pengertian umum bagaimana sebuah masjid harus dilihat, diberi nama, dipandang dari segi simbol-simbol yang diberikan.

Memberikan ungkapan simbolsimbol baru dalam arsitektur masjid agar. dapat diterima dan memberikan kebanggaan suatu masyarakat yang memilikinya adalah tuggas yang tidak mudah. Contoh yag cukup menarik untuk dipelajari, yaitu masjid Sherefudin, di Visoko. Yugoslavia, pemenang Aga Khan Award tahun 1983. Masjid ini menunjukkan interprestasi modern dari arsitektur masjid, dimana masjid dengan komunitasnya telah membangun sebuah ciri yang khas. Masjid ini mènjadi kebanggaan dari masyarakat dilingkungannya.

Berdasarkan uraian tersebut, ada beberapa hal yang perlu diperhatikan didalam mendesain masjid dari segi bentuk dan simbolnya, yaitu :

- Ungkapan bentuk simbol sudah semestinya berdasarkan motivasi untuk mengagungkan kebesaran Allah SWT, dengan cara mengkaji Al-Qur'an dán Sunnah Rosul, menjauhkan dari interprestasi yang menjurus kearah kemusyrikan.

- Masjid harus dapat menampung darisegi fungsi, sebagai sarana ibadahummat islam. Dalam konteks ini mencakup aspek-aspek kenyamanan pemakai ruang, seperti besaran ruang, pencahayaan, penghawaan, kelembaban dan aspek-aspek fisik lainnya. - Desain masjid sebaiknya menyesuaikan dengan sosial budaya dan konteks lingkungannya, serta menggunakan material - material lokal.

- Bentuk kubah, minaret dan lengkung bukanlah merupakan suatu keharusan yang mutlak digunakan. Namun terdapat juga kesempatan bagi arsitek untuk menafsirkan kembali bentuk kubah, minaret dan lengkung apabila elemen tradisional tersebut diterima arsitek.

- Pencapaian bentuk dan simbol dapat dilakukan dengan berbagai pendekatan, yakni vernakuler, historis, klasik kontemporer dàn modem. Tetapi tidak boleh lepas dari esensi masjid itu sendiri, yakni - sebagai sarana beribadah kepada Allah yang bersifat vertikal dan kegiatan kemasyarakatan yang bersifat horizontal. 
Fajriyanto, Simbol Dalam Arsitektur Masjid

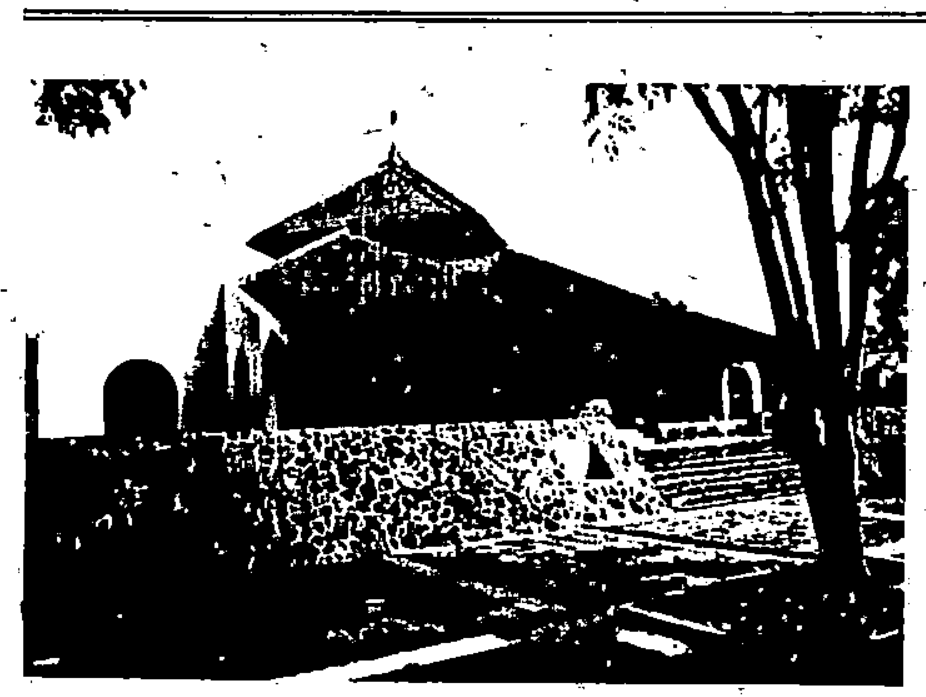

Masjid Said Naum, Jakarta contob pendekatan modern dengan cara adaptasi.

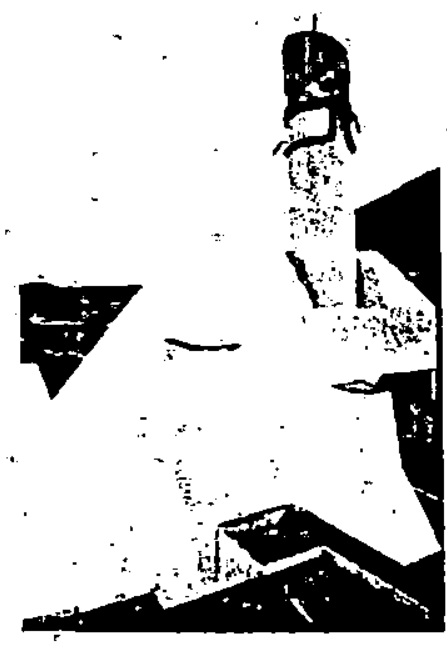

Masjid Sheréfudin, Yugoslavia menunjukkan suatu penafsiran modern dalam arsitektur masjid. 


\section{Daftar Pustaka}

Abdul Rochym, Sejarah Arsitektur Islam. Sebuah Tinjauan. Bandung : Angkasa, 1983.

Jencks, Charles, The Language of Post-Modern Architecture, New York: Rizzoli International Publications Inc, 1987

Proceedings of an International Seminar Spon: sored by the Aga Khan Award for Architecture and Indonesian Institute of Architects. Expressions. of Islam in Buildings. Indonesia : 15 - 19 Oktober 1990

Raharja, Bentuk Arsitektur Mesjid-mesjid-
Kerajaan di Jawa. Yogyakarta : Skripsi Jurusan Arkeologi Fakultas Sastra UGM, 1987.

Sidi Gazalba, Mesjid Pusat Ibadat dan Kebudayaan Islam. Djakarta : Pustaka Antara, 1962

Sugiarto Dakung, Arsitektur Tradisional Daerah Istimewa Yogyakarta. Jakarta:Proyek Inventarisasi dan Dokumentasi Kebudayaan Daerah, 1981/1982

Suwondo B. Sutedjo, Dipl. Ing. Peran, Kesan dan Pesan Bentuk-bentuk Arsitektur, Jakarta : Djambatan, 1982 